\title{
Study And Analysis Of a Bakelite Array Biocomposite Using Coconut Mesocarp Fibre And Tucumã Bark As Reinforcement
}

\author{
Flávio Júnior Santiago Silva ${ }^{1}$, Alinne Cristina Batista dos Santos ${ }^{2}$, Ana Emília Diniz Silva \\ Guedes $^{3}$
}

${ }^{1,2}$ Mechanical Engineering in Northern University Center (UNINORTE) - Manaus-AM

${ }^{3}$ Mechanical Engineering in Northern University Center (UNINORTE) - Manaus-AM

Email: flaviojrsantiago@gmail.com, alinnesantos19@hotmail.com, ana.guedes@uninorte.com.br

\author{
Received: February $18^{\text {th }}, 2019$ \\ Accepted: February $28^{\text {th }}, 2019$ \\ Published: March $31^{\text {th }}, 2019$ \\ Copyright (C2016 by authors and \\ Institute of Technology Galileo of \\ Amazon (ITEGAM). \\ This work is licensed under the \\ Creative Commons Attribution \\ International \\ License (CC BY 4.0). \\ http://creativecommons.org/licenses/by/4.0/ \\ (c) (1) (3) (2) Opean Actes:
}

\begin{abstract}
The aim of this article is to show that natural fibers extracted from the coconut mesocarp and Tucumã bark can be used as reinforcement for the Bakelite matrix, being a replacement for synthetic fibers. The fruits were submitted to a manual process to extract the fibers, then they were added with percentages of $0.01 \%, 0.015 \%$ and $0.02 \%$ in $(0.1 \%)$ Bakelite for the composites production, by a metallographic mounting press, followed by tests of hardness, accelerated aging and chemical characterization, where they obtained results of hardness of the composite with coconut fiber in $0.01 \%-79.3 \mathrm{HRB}, 0.015 \%-77.9 \mathrm{HRB}, 0,02 \%$ - $20.9 \mathrm{HRB}$, of the composite with Tucumã fiber in $0.01 \%-72.1 \mathrm{HRB}, 0.015 \%-83.7 \%, 0.02 \%-85 \%$ and that the sample without fiber had a hardness of $93 \mathrm{HRB}$. After the accelerated aging test, it was evidenced that there was no significant deterioration of the samples. In the chemical characterization, the moisture contents of the coconut was $11 \%$ and the Tucumã had $28 \%$, the extractives were $36 \%$ and 17 and ash contents of $0,16 \%$ and $0,78 \%$, respectively. Thus it was concluded that it can be used in areas of thermal and acoustic protection and even open a new window for further research
\end{abstract}

Keywords: Bakelite, Sustainable Composite, Flexible Assembly.

\section{INTRODUTION}

Composite materials are obtained by combining two or more materials with different properties, where one of the components is the matrix and the other is the reinforcement. This combination gives particular characteristics and specific properties to the product [1]. It involves mainly the areas of metal, ceramic and polymeric products manufacturing. For this project, the authors choose the polymeric matrix, since it has been widely used in the industry of the Manaus Industrial Pole (PIM).

Bakelite stands out since it is a polymer matrix resistant to high temperatures, forms rigid and homogeneous materials. They are very used in the manufacture of sockets, switches, thermal insulation materials, pots, phones, on production of some auto parts and tools [2].

Natural fibers used as reinforcement are extracted on a large scale of lignocellulosic composite materials with different physical, mechanical and chemical properties all over the Brazil [3]. One of the reasons for the use of natural fibers as reinforcement are their wide availability, occupying new market segments due to their low cost, biodegradability and renewability, non-toxic and good mechanical properties [4].
Based on that, many researches have been assessed in order to evaluate the feasibility of natural fibers as an alternative to synthetic fibers, conventionally used as reinforcement in the polymeric matrix [5].

Therefore, in the search for these raw materials, the Tucumã fruit (Astrocaryum aculeatum) and coconut (Cocos nucifera) are highlighted since they are two typical fruits of the Amazon region and are highly used in the local cuisine, which their biomass do not have value, being discarded improperly, harming the environment.

\section{THEORETICAL REFERENCE}

\section{II.1 TUCUMÃ}

The Tucumã palm tree (Astrocaryum Aculeatum) is considered a pioneer plant with an aggressive growth and capable to grow new sprouts even after a fire, mainly it inhabits secondary forests and pastures [6]. The Tucumã (Astrocaryum vulgare Mart. - Arecaceae) also known as Tucumã-of-Pará, is widely distributed in Venezuela, Trinidad, Guianas, Bolivia and in the Brazilian Amazon. In Brazil, it can be found in the states of Amazonas, 
Pará, Rondônia, Mato Grosso and Acre [7]. The fruit also has soft and fibrous pulp, with an orange yellow coloration, rich in vitamins and highly appreciated by the Amazonian people as a traditional food delicacy, widespread in typical regional cuisine [8].

The Tucumã seed is covered by an orange and oily pulp. On average, the fruit weighs 30 grams, 34\% of this weight correspond to the external pulp that has between $14 \%$ to $16 \%$ of the oil when its raw. An adult tree can produce up to $50 \mathrm{~kg}$ of fruit per year, 25 kilos per tree on average, which corresponds to 2.5 kilos of pulp oil and 1.5 kilos of seed oil. In one hectare, about 400 bunches of palm trees can be planted, resulting in 4.8 tons of raw material [9].

\section{II.2 COCONUT}

The coconut tree (Cocos nucifera) is a member of the Arecaceae family (palm family). It has a flat cylindrical stipe palm, that can reach up to $20 \mathrm{~m}$ high. This tree produces an ovoid fruit, about $15 \mathrm{~cm}$ in diameter, which, when ripe, presents brown coloration. It has an abundant pulp, up to $2 \mathrm{~cm}$ thick that contain an aqueous or milky liquid, known as coconut water, in the inner portion.

The unripe coconut or green coconut is responsible for about 80 to $85 \%$ of the crude mass represent residue (shells), which have not been processed by the fiber processing industry, due to the lack of knowledge of its properties. The shells of the green coconut have been discarded in the landfill and open-pit (dumps). As every organic matter, they are a potential generators of gases and contribute to diminished these deposits lifetime, proliferating outbreaks of diseases vectors, stench, contamination of the soil and water, in addition to the inevitable destruction of the urban landscape [10]. The northern region has the second largest coconut production, behind the Northeast region, as shown in Table 1 .

Table 1: Percentages of regional participation in production and harvested area of coconut and productivity evolution, between the years of 1985 and 2011.

\begin{tabular}{|c|c|c|c|c|c|}
\hline Region & $\begin{array}{c}\text { Production } \\
(\%)\end{array}$ & $\begin{array}{c}\text { Area } \\
\text { harvested } \\
(\%)\end{array}$ & $\begin{array}{c}\text { Productivity } \\
(\%)\end{array}$ \\
\hline & 1985 & 2011 & 1985 & 2011 & 1985 \\
\hline Northeast & 94,4 & 70 & 96,2 & 81,1 & 86,6 \\
\hline North & 3,8 & 12,9 & 2,3 & 9,9 & 66,4 \\
\hline Southeast & 1,8 & 15,2 & 1,5 & 7,8 & 234,1 \\
\hline
\end{tabular}

Source: IBGE, (2013).

\section{II.3 BAKELITE}

Phenolic resins are one of the first polymeric products produced commercially and used by the industry. The first commercially viable product from phenolic resins was developed by Leo Hendrik and was called Bakelite. It was made from the mixture of phenolic resin, interweaving agent, wood or mineral fibers, molded by temperature and pressure. The pieces molded with this material showed high resistance to temperature [11].

The combination of properties such as good dimensional stability, high hardness, stiffness, wear resistance and heat, low density, allied to low manufacturing cost, makes this material an important alternative to replacing other materials in many segments, such as metal, ceramics and wood. An important feature that must be highlighted in the Bakelite manufacturing industry is the molding easiness that this resin possesses, requiring low complexity equipment of mechanical construction [12].

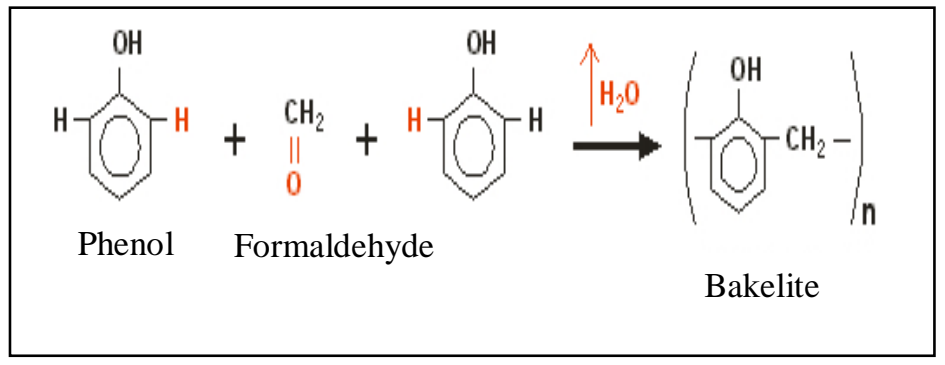

Figure 1: Bakelite chemical estructure.

Sourece: Adaptated from website Mundo educação - Bakelite Polimer, (2018).

\section{MATERIALS E METHODS}

First, the fiber of the Tucumã bark and coconut mesocarp were extracted, then the specimens were produced along with the Bakelite polymeric matrix using a metallographic mounting press for analysis. After that, the hardness test, accelerated ageing test and chemical quantification of the raw materials were performed.

\section{III.1 EXTRACTION OF THE COCONUT FIBER}

The coconuts were obtained from the Manauara market. The first stage of the coconut mesocarp extraction was constituted by the husks dispersion and natural drying for three days, so the coconut fibers would be easier to extract, until they had a thinner texture, Figure 2 [13].

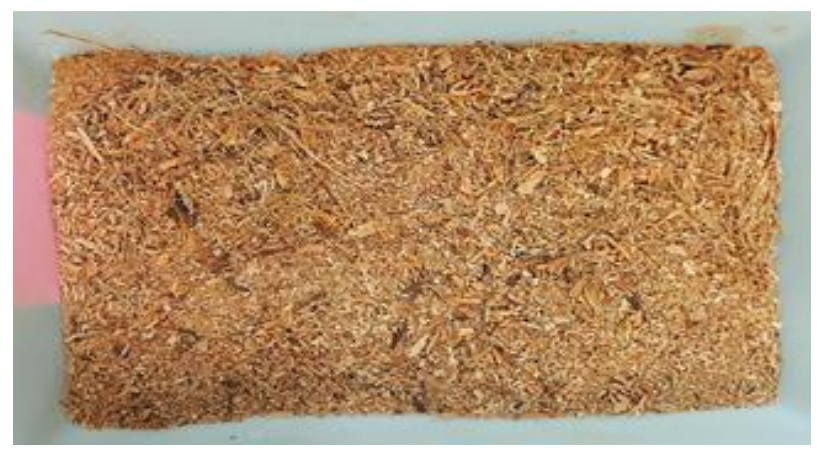

Figure 2: Coconut mesocarp fiber.

Source: Authors, (2018).

\section{III.2 EXTRACTION OF THE TUCUMÃ FIBER}

The Tucumã used to extract the fiber were obtained from the modern Manaus fair, located in the city of Manaus, area of intense fruit commercialization. The bark of the Tucumã was washed in running water, in order remove its oiliness, after this, a quantity of bark was placed in an Erlenmeyer containing distilled water and submitted to magnetic stirring during 30 minutes at $70^{\circ}$ $\mathrm{C}$, this process was measured from the boiling point of the solution and it was performed twice the exchange of distilled water, after this process, the Tucumã bark was dried for 2 hours in the industrial oven at $100^{\circ} \mathrm{C}$, in order to reach the ideal point, Figure 3. 


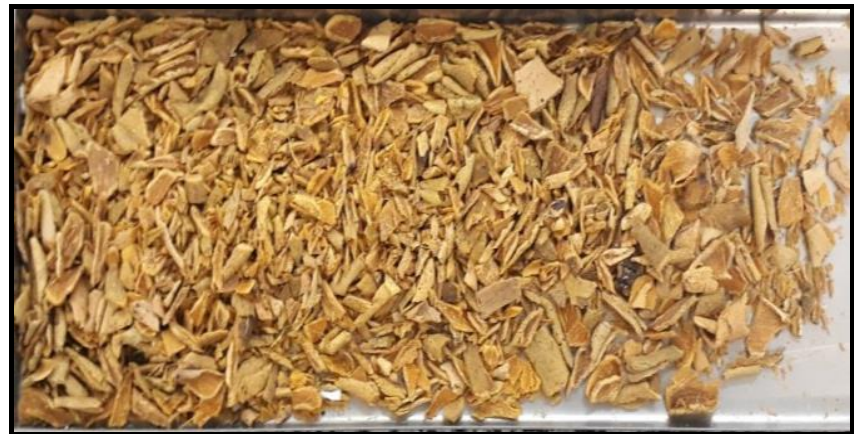

Figure 3: Tucumã Bark after fiber extraction process 2.2 Source: Authors, (2018).

\section{III.3 PRODUCTION OF SPECIMENS BY AN INDUSTRIAL METALLOGRAPHIC MOUNTING PRESS ADDITION OF COCONUT FIBER WITH BAKELITE}

For the production of the specimens, the standard procedure disposed in the metallographic mounting press manual was followed. It was weighed in an analytical balance $10 \mathrm{~g}(0.1 \%)$ of pure Bakelite and $1 \mathrm{~g}(0.01 \%)$ of the coconut fiber. Then, they were inserted in the filler. A programming must be done to start the molding cycle, specifying the temperature and process time. The hydraulic unit must be depressurized, with the relief valve closed, and before starting the cycle it necessary to lubricate the cylinder and the molding pistons with a thin layer of demolded spray in the inlay. This process was performed at a temperature range of $100^{\circ} \mathrm{C}$ and $150^{\circ} \mathrm{C}$, at a stabilized pressure of 150 $\mathrm{kgf} / \mathrm{cm}^{2}$ during 30 minutes, and 5 minutes for refrigeration. The same production pattern was used for manufacturing the other specimens. The Bakelite content was maintained $(0.1 \%)$ while the percentage of coconut fiber was increased to $1.5 \mathrm{~g}(0.015 \%)$ and $2 \mathrm{~g}(0.02 \%)$ [14].

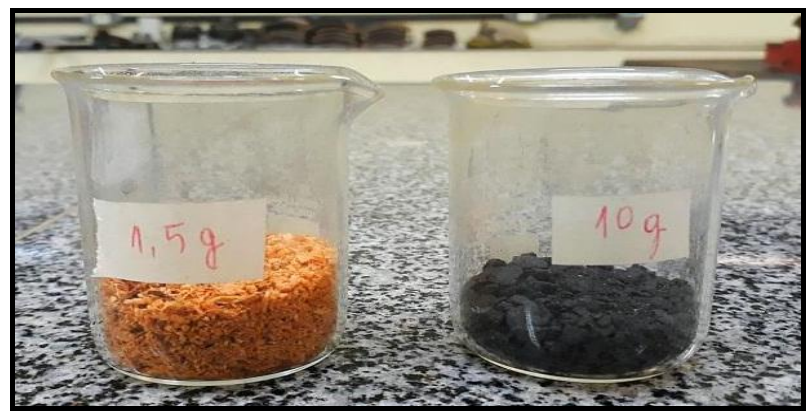

Figure 4: Sample before the filler process. Source: Authors, (2018).

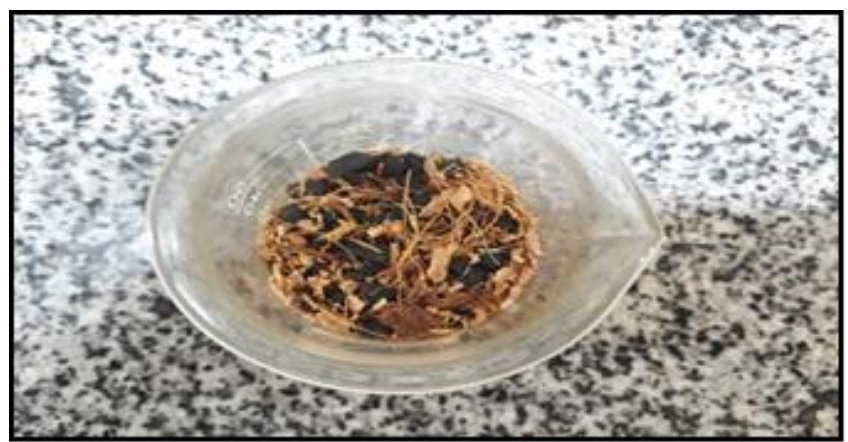

Figure 5: Materials homogeneous mixed. Source: Authors, (2018)

\section{III.4 ADDITION OF TUCUMÃ FIBER WITH BAKELITE}

To produce the specimens using the Tucumã fiber as reinforcements in the polymeric matrix, the authors used the same methods from item III.3- Addition of coconut fiber with Bakelite. The only difference was the type of fiber used.

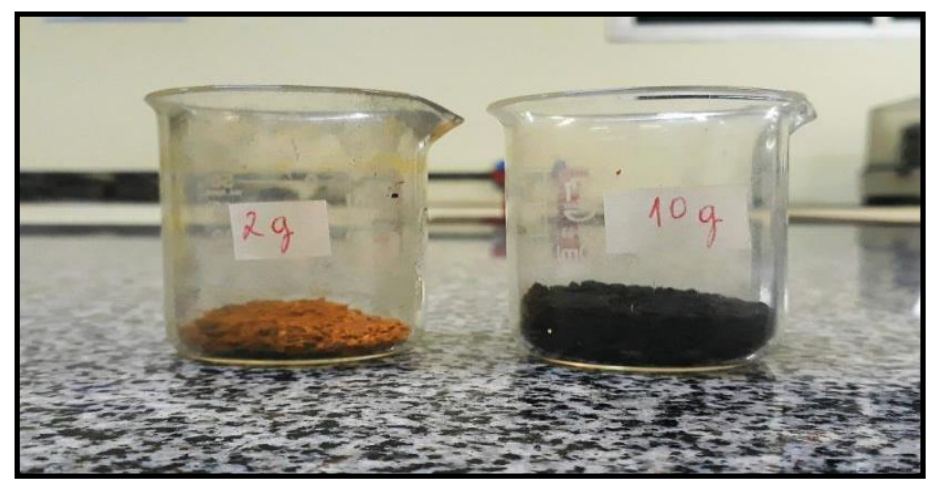

Figure 06: Samples before the filler process.

Source: Authors, (2018).

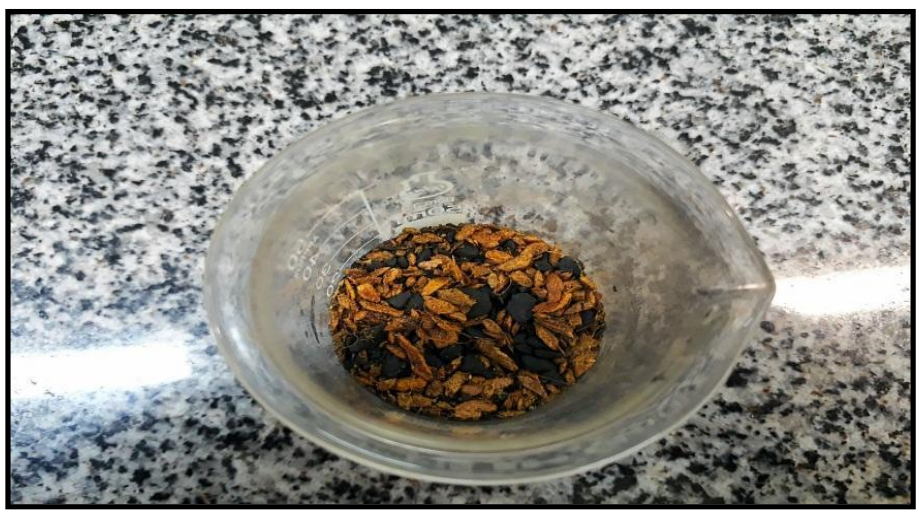

Figure 7: Materials homogeneous mixed.

Source: Authors, (2018).

\section{III.5 HARDNESS TEST}

After the production of the specimens, hardness tests were performed on the composite samples separately. Three indentations were performed in each one, and the arithmetic mean of the three indentations was added. For this, the authors used a Rockwell hardness tester (digital) - HRA-HRB-HRC, with applications in rolling alloys, soft metals or fine materials, including plastics, with $1 / 4$ " ball penetrator and $60 \mathrm{~N}$ of load. The specimen was positioned on the table and the pre-load on the Rscale, then the steering wheel was rotated clockwise until the specimen came in contact with the penetrator, depending on the steering wheel rotation. The indicator increased until it was complete on the front panel of the durometer. During the test, the equipment performed the times of pre-load cycle (T-A), total load (T-B) and pre-load (T-C), then the test result was displayed on the indicator.

\section{III.6 ACCELERATED AGING}

For this test the specimens with coconut and the Tucumã fibers percentages of $0.01 \%, 0.015 \%$ and $0.02 \%$ were subjected to an accelerated aging test according to ISO 4892. Where the composites were placed in previously weighted crucibles, at a temperature of $150{ }^{\circ} \mathrm{C}$ for seven days in a muffle. Their state was 
observed every day [15]. After this process, hardness tests were performed again following the procedures in item 2.5- Hardness test.

\section{III.7 DETERMINATION OF THE FIBERS MOISTURE CONTENT}

In order to determine the moisture content, the authors used 1g sample of the coconut and Tucumã fiber, and followed the procedures of the oven drying method. This method consists in placing a known mass of the material in an industrial oven at $105^{\circ} \mathrm{C}$ for 1 hour. Then, the difference between the initial and final mass of the material is evaluated, calculating the moisture content according to NBR 7190 (ABNT, 1997).

$$
\mathrm{U}(\%)=\frac{(M i-M s)}{M s} \times 100=
$$

Where: $\mathrm{U}(\%)=$ moisture content; $\mathrm{mi}=$ initial mass of the sample in grams; and $\mathrm{ms}=$ final mass of the sample in grams .

\section{III.8 DETERMINATION OF THE FIBER EXTRACTIVES}

The Tucumã and coconut fiber were treated in distilled water and ethanol to remove organic compounds of low molar mass. Then, the authors weighed $3 \mathrm{~g}$ of each fiber on analytical balance. Each one was placed into a round bottom flask attached to a reflux condenser, where $300 \mathrm{~mL}$ of ethanol and distilled water solution (1:1) was added. The system was kept under reflux for 30 minutes, measured from the boiling point of the solution. After this procedure, the fibers were filtered separately by a filter paper that was previously weighted and with a known moisture content. Then, the paper filter and residue were dried in an oven, initially at $40{ }^{\circ} \mathrm{C}$ for 2 hours and $100^{\circ} \mathrm{C}$ for 1 hour. The initial low temperature was applied in order to avoid the thermal degradation of polysaccharides (cellulose and hemicellulose) and lignin.

$$
S(\%)=\frac{(M 1-M 2)}{M 2} \times 100=
$$

Where: $\mathrm{S}(\%)=$ extractive content; $\mathrm{m} 1(\mathrm{~g})=$ mass of the sample before the water/ethanol extraction; and $\mathrm{m} 2(\mathrm{~g})=$ mass of sample after the extraction.

\section{III.9 ASH CONTENTS OF THE FIBERS}

For the determination of the ash content or inorganic content, the samples were placed inside porcelain crucible that were in a muffle at a temperature of $600^{\circ} \mathrm{C}$ during 3 hours, seeking for the complete thermal degradation of organic compounds. The calcined samples were placed in a desiccator to cool until room temperature. The ash content was calculated according to standard TAPPI T-211 om-85 (TAPPI, 1999a).

$$
\operatorname{Cinzas}(\%)=\frac{(P c)}{P} \times 100=
$$

Where: Ash $(\%)=$ ash content; $\mathrm{Pc}=$ weight of $\operatorname{ash}(\mathrm{g})$; and $\mathrm{P}=$ weight of sample dried in the industrial oven(g) [16].

\section{RESULTS AND DISCUSSION}

The composites produced by the metallographic mounting press due to the fiber inclusion, there was an increase of $2 \mathrm{~cm}$ in the thickness, and they were very resistant, similar to the sample produced without natural fiber, $15 \mathrm{~cm}$ diameter and $10 \mathrm{~cm}$ thick, with any fiber showing off, only with their odor.

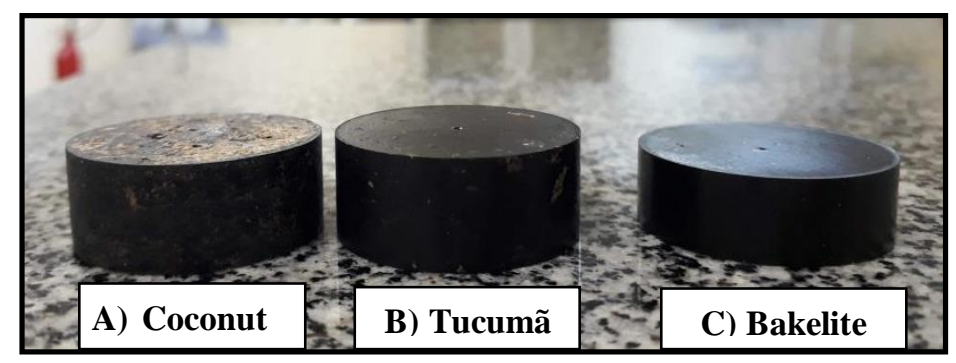

Figure 08: Composites produced by the metallographic mounting press.

Source: Authors, (2018).

\section{IV.1 HARDNESS TEST}

It can be observed that there was a decrease in the hardness value. Indirectly, it is assumed that the addition of fiber makes the composite more tenacious, since the energy dissipates more evenly through the fibers. The graphs 01,02 , and 03 show the HRB hardness according to ABNT NBR 9630 for determination of plastics hardness.

The polymeric matrix supports a hardness of 93 HRB without addition of natural fiber. When the coconut fiber was added, the result of hardness shifts to $79.3 \mathrm{HRB}$ at $0.01 \%, 77.9$ $\mathrm{HRB}$ at $0.0015 \%$ and $20.9 \mathrm{HRB}$ at $0.02 \%$, reducing the value obtained without the fiber. The addition of Tucumã fiber followed the same percentages, however different results were obtained, graph 03. Thus, it appears that the greater the amount fiber the lower the matrix hardness, compensating with the increased flexibility of the specimen. According to PAIVA, these results could indicate that the presence of fibers decreases the mechanical resistance to another body penetration, a consequence of the fibers hygroscopicity [17].

However, one can see that the polymer matrix with $0.02 \%$ of Tucumã fiber has higher resistance than the coconut fiber at the same percentage, with a small difference of $8 \mathrm{HRB}$ in relation to Bakelite without fiber.

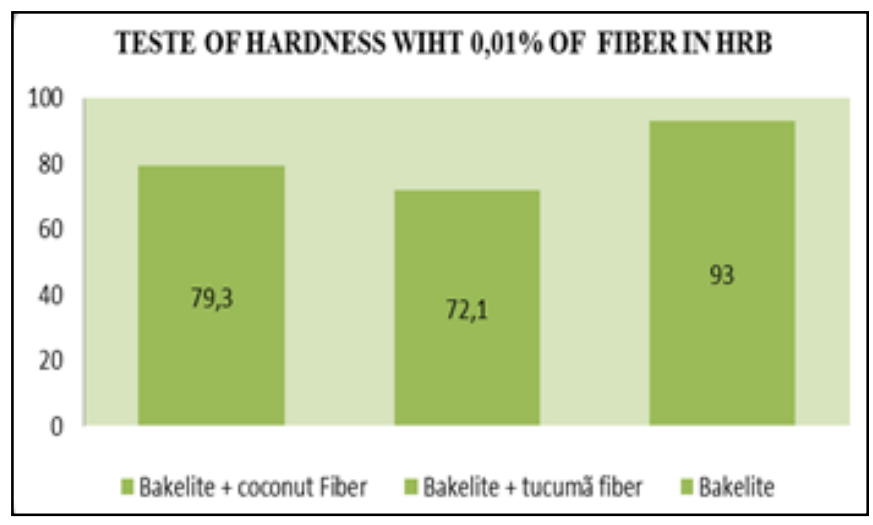

Figure 9: Hardness test performed with $0.01 \%$ of Coconut and Tucumã fiber.

Source: Authors, (2018). 
TESTE OF HARDNESS WIHT 0,015\% OF FIBER IN HRB

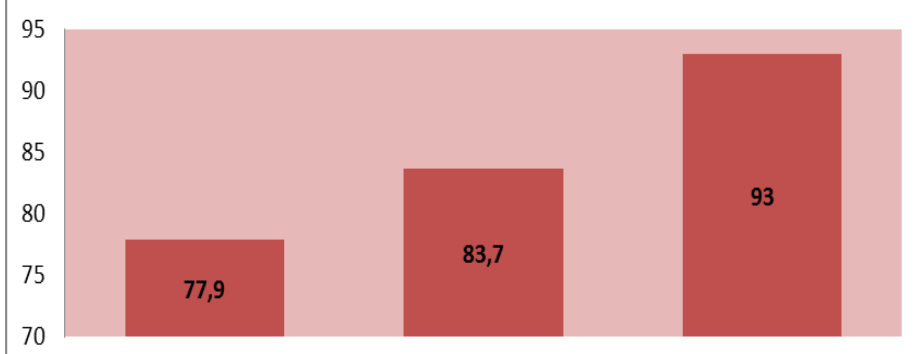

- Bakelite + coconut Fiber $\quad$ Bakelite + tucumã fiber B Bakelite

Figure 10: Hardness test performed with $0.015 \%$ of Coconut and Tucumã fiber.

Source: Authors, (2018).

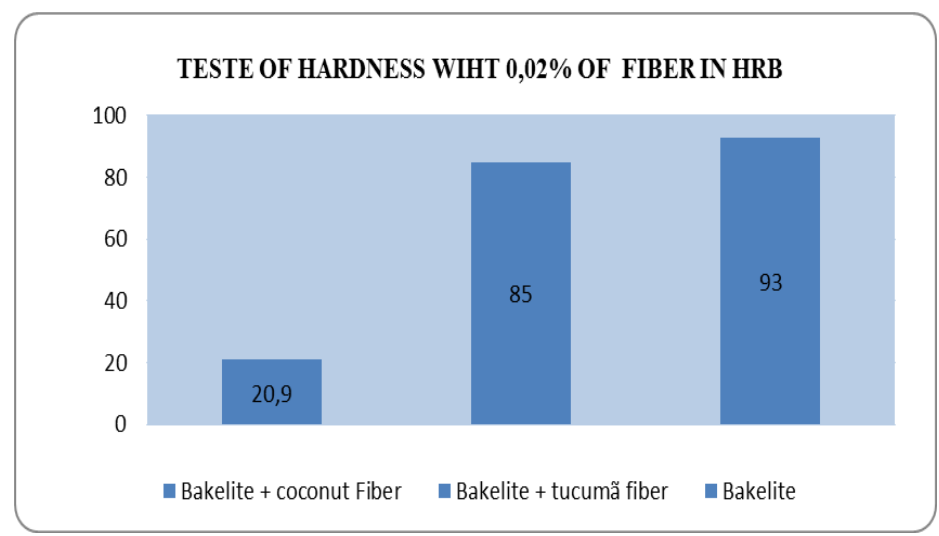

Figure 11: Hardness test performed with $0.02 \%$ of Coconut and Tucumã fiber.

Source: Authors, (2018).

\section{IV.2 ACCELERATED AGING TEST}

After the accelerated aging process, inside a muffle for 7 days at $150^{\circ} \mathrm{C}$, it was observed that the samples had a low deterioration, low fatigue aspect, i.e. did not have a very high impact to the naked eye, therefore it can be used in internal and external environments.

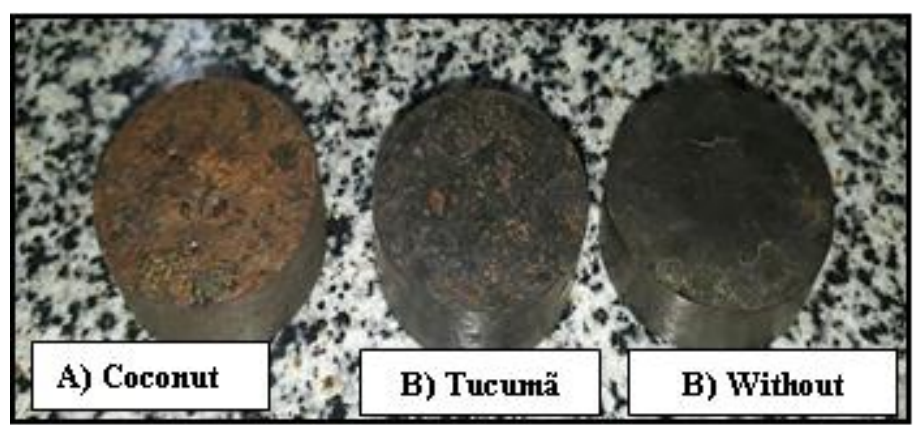

Figure 12: Results after accelerated aging test. Source: Authors, (2018).

\section{IV.3 CHEMICAL CHARACTERIZATION}

Table 1 shows the results of the chemical analysis for the sample with Coconut and Tucumã fiber. It can be observed that the moisture content for the coconut and for the Tucumã was $0,11 \%$ and $28 \%$. The ash content is related to the amount of inorganic matter present in the fiber, the coconut presented a low amount of ashes content, while the Tucumã fiber showed a $0,78 \%$ [18]. According to the literature the value generally varies from $0.1 \%$ to $1.0 \%$ in general woods, comparing the similar texture with the fibers produced. With this, it can be seen that the fiber of the tucumã obtained a great gray content. The extractive content found had a difference of $19 \%$ between the fibers, a value higher than what is agreed by the researchers, when compared to wood straw that are usually found extractive contents of 7,0\% [18].

Table 2: Percentage of chemical characterization with $3 \mathrm{~g}$ of each fiber.

\begin{tabular}{|c|c|c|c|}
\hline Fiber & Moisture (\%) & Extrative (\%) & Ash (\%) \\
\hline Coconut & $11 \%$ & $36 \%$ & $0,16 \%$ \\
\hline Tucumã & $28 \%$ & $17 \%$ & $0,78 \%$ \\
\hline
\end{tabular}

Source: Authors, (2018).

\section{CONCLUSIONS}

Based on the results found on this article, it is clear that the two fibers had a similar behavior when incorporated into Bakelite matrix. A significant improvement to the tenacity due to the reduction of hardness with good stability and degradation was observed in this study, therefore it can be applied in various areas for thermal and acoustic protection. However, a vast application window can be discover by researchers using other types of polymers and natural fibers.

\section{ACKNOWLEDGMENTS}

I thank all those who contributed to this work, our advisor Prof. Dr. Ana Emília Guedes for her pro activity with us, the laboratory technicians, Angelica and Sidney, for all patience and availability during these months. Alanna Gouvêia for being one of the motivators to use the local raw material and to the Northern University Center - UNINORTE for the structure offered.

\section{REFERENCES}

[1] Oliveira, M. S de: Desenvolvimento e caracterização de telhas cimentícias reforçadas com tecido de fibras vegetais da Amazônia. 2017. 118 f. Dissertação (Mestrado em Engenharia Civil) - Universidade Federal do Amazonas, Manaus, 2017.

[2] Ramires, E. C: Biocompósitos a partir de matrizes poliméricas baseada em lignina, tanino e glioxal reforçados com fibras naturais, 2010. Tese (Doutorado em Ciências físico-químico) Universidade de São Paulo, São Carlos, 2010.

[3] Giacomini, N. P; Compósitos reforçados com fibras naturais para indústria automobilística. 2003. Dissertação (Mestrado em Ciência e Engenharia dos Materiais) - Universidade de São Paulo, São Carlos, 2003.

[4] Paula, G. P; Formulação e caracterização de compósitos com fibras vegetais e matriz termoplástica. 2011. Dissertação (Mestrado em Ciência e Engenharia dos Materiais) Universidade Estadual do Norte Fluminense Darcy Ribeiro, Campos de Goytacazes, RJ, 2011. 
[5] Marinelli, A. L. et al. - Desenvolvimento de compósitos poliméricos com fibras vegetais naturais da biodiversidade: Polímeros: Ciência e Tecnologia, vol. 18, nº 2, p. 92-99, 2008.

[6] Souza, S, R, G de; 2013; A produção de biodiesel a partir da amêndoa do tucumã no Amazonas; Publicado em XXXIII Encontro nacional de engenharia de produção.

[7] Lima, R. R; Trassato, L. C. \& Coelho, V. 1986. O tucumã (Astrocaryum vulgare Mart.). Principais características e potencialidade agroindustrial. Belém: EMBRAPA-CPATU (Boletim de Pesquisa 75); [online] Disponível em: http://www.infoteca.cnptia.embrapa.br/infoteca/handle/doc/38096 5.

[8] Monteiro, J. H. de. S: Proposta de desenvolvimento de processo industrial na produção de polpa de tucumã: um estudo de caso na cidade de Manaus. Dissertação (Mestrado em Engenharia de processo) - Universidade Federal do Pará, Belém PA, 2017.

[9] Souza, S, R, G de; 2013; A produção de biodiesel a partir da amêndoa do tucumã no Amazonas; Publicado em XXXIII Encontro nacional de engenharia de produção.

[10] Corradini, E; Rosa, M, de, F; Macedo, B. P. de; Paladini, P. D; Mattoso, L. H. C: Composição química, propriedades mecânicas e térmicas da fibra de frutos de cultivares de coco verde: Rev. Bras. Frutic. Jaboticabal - SP, v. 31, n. 3, p.837-846, Setembro 2009.

[11] Tillmann, L; Avaliação da viabilidade de utilização do resíduo de baquelite como componente de peças refratárias. Trabalho de Conclusão de Curso (graduação em Engenharia Ambiental) - Universidade do Tuiuti do Paraná, Curitiba, 2011.

[12] Canto, L. B. Cavalcante, A. P; Avaliação do efeito da incorporação de resíduo de baquelite sobre as propriedades mecânicas do polipropileno. 2009. Publicado em Anais do $10^{\circ}$ Congresso Brasileiro de Polímeros - Foz do Iguaçu, PR Outubro/2009.

[13] Neto, J. M De M; Cirne, L. E Da M. R; Pedroza, J. P; Silva, M. G da: Componentes químicos da farinha de banana (musa sp.) obtida por meio de secagem natural: Revista brasileira de engenharia agrícola e ambiental, v.2, n.3, p.316-318, 1998.

[14] Rohde, R. A; Metalográfia preparação de amostras: uma abordagem prática versão - 3.0; Outubro - 2010, LEMM Laboratório de Ensaios Mecânicos e Materiais; Disponível em: www.urisan.tche.br/ lemm.

[15] OHLSON, O de C; KRZYZANOWSKI, F, C; CAIEIRO, J, T; PANOBIANCO, M: Teste de envelhecimento acelerado em sementes de trigo: (Dissertação de Mestrado) - Universidade Federal do Paraná, publicado na Revista Brasileira de Sementes, vol. $32, n^{\circ} 4$ p. 118 - 124, 2010.

[16] Mirando, R. O .V de; Racantt, H; Machado, G de O; Soares, I. D; Roik, M; Caracterização química e potencial de utilização da madeira de Hovenia dulcis Thunb; Publicado em ENCICLOPÉDIA BIOSFERA, Centro Científico Conhecer Goiânia, v.9, n.17; p. 2013

[17] Paiva, J. M. F. Trindade, W. Frollini G. E: Compósitos de Matriz Termofixa Fenólica Reforçada com Fibras Vegetais. 1999. Publicado em: Polímeros: Ciência e Tecnologia - Out/Dez, p 170: 17.

[18] Mirando, R. O .V de; Racantt, H; Machado, G de O; Soares, I. D; Roik, M; Caracterização química e potencial de utilização da madeira de Hovenia dulcis Thunb; Publicado em ENCICLOPÉDIA BIOSFERA, Centro Científico Conhecer Goiânia, v.9, n.17; p. 2013 